\title{
A Fentanyl Vaccine Alters Fentanyl Distribution and Protects against Fentanyl-Induced Effects in Mice and Rats
}

\author{
Michael D. Raleigh, Federico Baruffaldi, Samantha J. Peterson, Morgan Le Naour, \\ Theresa M. Harmon, Jennifer R. Vigliaturo, Paul R. Pentel, and Marco Pravetoni \\ Hennepin Healthcare Research Institute (formerly Minneapolis Medical Research Foundation), Minneapolis, Minnesota (M.D.R., \\ F.B., S.J.P., T.M.H., J.R.V., P.R.P., M.P.); Department of Medicinal Chemistry, University of Minnesota College of Pharmacy \\ Minneapolis, Minnesota (M.L.N.); MLN BioPharma Consulting LLC (M.L.N.) Minneapolis, Minnesota; and Departments of \\ Pharmacology (M.P.) and Medicine (P.R.P., M.P.), and Center for Immunology (M.P.), University of Minnesota Medical School, \\ Minneapolis, Minnesota
}

Received September 19, 2018; accepted November 7, 2018

\begin{abstract}
Fentanyl is an extremely potent synthetic opioid that has been increasingly used to adulterate heroin, cocaine, and counterfeit prescription pills, leading to an increase in opioid-induced fatal overdoses in the United States, Canada, and Europe. A vaccine targeting fentanyl could offer protection against the toxic effects of fentanyl in both recreational drug users and others in professions at risk of accidental exposure. This study focuses on the development of a vaccine consisting of a fentanyl-based hapten $(F)$ conjugated to keyhole limpet hemocyanin $(\mathrm{KLH})$ carrier protein or to GMP-grade subunit $\mathrm{KLH}(\mathrm{sKLH})$. Immunization with F-KLH in mice and rats reduced fentanyl-induced hotplate antinociception, and in rats reduced
\end{abstract}

fentanyl distribution to the brain compared with controls. F-KLH did not reduce the antinociceptive effects of equianalgesic doses of heroin or oxycodone in rats. To assess the vaccine effect on fentanyl toxicity, rats immunized with F-sKLH or unconjugated sKLH were exposed to increasing subcutaneous doses of fentanyl. Vaccination with F-sKLH shifted the dose-response curves to the right for both fentanyl-induced antinociception and respiratory depression. Naloxone reversed fentanyl effects in both groups, showing that its ability to reverse respiratory depression was preserved. These data demonstrate preclinical selectivity and efficacy of a fentanyl vaccine and suggest that vaccines may offer a therapeutic option in reducing fentanyl-induced side effects.

\section{Introduction}

Opioid use disorders (OUDs) and the fatal overdose epidemic have been a growing public health burden with over 33,000 opioid-related deaths in 2015 in the United States alone (Rudd et al., 2016). The incidence of fatal overdoses from synthetic opioids increased 100\% from 2015 to 2016, largely driven by illicitly manufactured fentanyl (Rudd et al., 2016; Seth et al., 2018). Fentanyl and its analogs have been involved in more than $50 \%$ of opioid-related fatalities in the United States (O'Donnell et al., 2017). Fentanyl (Fig. 1A) is a schedule II opioid agonist with an extremely high in vivo potency of 100-200 times than that of morphine and has been increasingly used as an adulterant in heroin and counterfeit prescription opioids because of its potency, ease of chemical feasibility, and low manufacturing costs (Schneider and Brune, 1986; Molina-Martinez et al., 2014; DEA, 2016b; Frank and Pollack, 2017). Overdose deaths from heroin or

This work was supported by the National Institutes of Health National Institute on Drug Abuse [Grants DA026300, DA038876].

https://doi.org/10.1124/jpet.118.253674. hydrocodone/acetaminophen laced with fentanyl or its derivatives carfentanil, acetylfentanyl, and alfentanil have been increasingly reported in North America (Armenian et al., 2018). The presence of fentanyl was also recorded in fatal overdoses related to cocaine, benzodiazepines, antidepressants, and other counterfeit or illicit drugs (Jones et al., 2018). In addition to fentanyl misuse in patients with OUD, fentanyl and its derivatives have also been used as chemical agents for incapacitation in military scenarios (Riches et al., 2012). Finally, fentanyl and its analogs pose a potential risk for law enforcement officials, first responders, airport or custom personnel, and their canine units (DEA, 2016a). These data suggest that the development of novel treatment modalities to reduce the incidence or severity of accidental overdoses from fentanyl and its derivatives could have a substantial public health impact.

The current treatment of fentanyl overdose is naloxone, an opioid antagonist. Distribution of naloxone to high-risk populations is being expanded in the United States and has been shown to be a cost-effective strategy for decreasing overdose deaths in both the United States and UK (Wheeler et al., 2015; Langham et al., 2018). However, for naloxone to be effective,

ABBREVIATIONS: br, broad; BSA, bovine serum albumin; d, doublet; DIPEA, $N, N$-diisopropylethylamine; ESI, electrospray ionization; F, fentanylbased hapten; F-BSA, fentanyl-based hapten conjugated to bovine serum albumin; F-KLH, fentanyl-based hapten conjugated to keyhole limpet hemocyanin; HBTU, 2-(1H-benzotriazol-1-yl)-1,1,3,3-tetramethyluronium hexafluorophosphate; KLH, keyhole limpet hemocyanin; m, multiplet; MALDI, matrix-assisted laser desorption/ionization; \%MPE, percentage maximum possible effect; MS, mass spectrometry; $m / z$, mass/charge ratio; OUD, opioid use disorder; OVA, ovalbumin; s, singlet; $\mathrm{SaO}_{2}$, arterial oxygen saturation; t, triplet; TFA, trifluoroacetic acid; TOF, time of flight. 
A

\section{Fentanyl}<smiles>CCC(=O)N(c1ccccc1)C1CCN(CCc2ccccc2)CC1</smiles>

B Fentanyl hapten

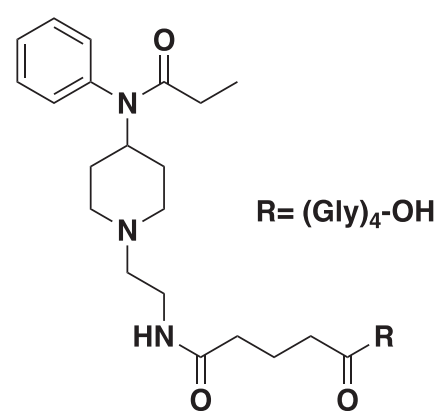

Fig. 1. Structure of fentanyl (A) and F (B).

administration is required shortly after exposure and with proper technique. Because of this consideration, as well as the potency of fentanyl, naloxone may not always be sufficient to rapidly reverse fentanyl-induced respiratory depression (Clarke et al., 2005; Tomassoni et al., 2017). Also, the administration of naloxone may precipitate opioid withdrawal syndrome and cause severe side effects (Evans et al., 1973; Clarke et al., 2005; Rzasa Lynn and Galinkin, 2018). Prophylactic vaccination against fentanyl could be a cost-effective, longlasting intervention to reduce the incidence or severity of fentanyl overdose.

Opioid vaccines have been explored preclinically as a treatment of OUD and have been effective in rodent and nonhuman primate models (Stowe et al., 2011; Bremer and Janda, 2012; Pravetoni et al., 2012b; Matyas et al., 2013; Raleigh et al., 2013, 2014, 2017; Schlosburg et al., 2013; Bremer et al., 2014, 2017). Opioid vaccines elicit opioid-specific antibodies that bind to the targeted opioids in the blood and reduce their distribution to the brain, reducing their behavioral and toxic effects. Vaccine efficacy is greatest when the levels of antibody produced are high and the opioid dose is low. Because fentanyl is quite potent and has a relatively low toxic dose compared with other abused opioids such as heroin or oxycodone, it is a particularly attractive candidate for this approach.

A limited number of studies showed preclinical proof of concept for immunotherapy against fentanyl and its analogs in mice, rabbits, and dogs (Torten et al., 1975; Bremer et al., 2016; Hwang et al., 2018). These studies showed that fentanyl-specific antibodies reduced hotplate antinociception and fentanyl-induced respiratory depression after small fentanyl doses (Torten et al., 1975; Bremer et al., 2016; Hwang et al., 2018). These studies involved either passive immunization with polyclonal antibodies or active vaccination using Freund's complete adjuvant intradermally (Henderson et al., 1975; Torten et al., 1975) or other adjuvants administered intraperitoneally (Bremer et al., 2016; Hwang et al., 2018), which may not be feasible in humans. The aim of this study was to determine the efficacy of a fentanyl vaccine adsorbed on alum adjuvant and administered intramuscularly in mice and rats. The fentanyl vaccine was developed using a fentanylbased hapten $(\mathrm{F})$ conjugated to either the native decamer keyhole limpet hemocyanin (KLH) carrier protein or the GMPgrade subunit KLH ( $\mathrm{KKLH}$ ) by means of a tetraglycine linker using carbodiimide chemistry to create F-KLH and F-sKLH, respectively. This vaccine design is analogous to other opioid vaccines that are being prepared for clinical use (Raleigh et al., 2017, 2018). Mice and rats immunized with F-KLH had lower fentanyl-induced antinociception compared with controls. Rats immunized with F-KLH had lower brain fentanyl concentrations after an intravenous dose of fentanyl compared with controls. In a separate cohort of rats, F-sKLH reduced fentanylinduced hotplate antinociception, respiratory depression, and bradycardia over a range of cumulative subcutaneous fentanyl doses. Together, these data suggest that a fentanyl vaccine could be a viable option for reducing the depressive effects on respiration of fentanyl in humans.

\section{Materials and Methods}

\section{Ethics Statement}

These studies were carried out in strict accordance with the recommendations in the Guide for the Care and Use of Laboratory Animals of the National Institutes of Health. Animal protocols were approved by the Hennepin Healthcare Research Institute Animal Care and Use Committee. Surgery was performed under ketamine $(75 \mathrm{mg} / \mathrm{kg})$ and dexmedetomidine $(0.05 \mathrm{mg} / \mathrm{kg})$ anesthesia, animals were euthanized by $\mathrm{CO}_{2}$ inhalation using Association for Assessment and Accreditation of Laboratory Animal Care International-approved chambers, and all efforts were made to minimize suffering.

\section{Overview of the Fentanyl-Hapten Synthesis}

F (Scheme 1, [8]) was synthesized as depicted in Scheme 1. Briefly, piperidone monohydrate hydrochloride (Scheme 1, [1]) propanamide was alkylated with 2-(Bocamino)ethylbromide in the presence of potassium carbonate in acetonitrile to provide the $N$-substituted piperidine intermediate (Scheme 1, [2]) with good yield. Reductive amination with aniline of $N$-substituted piperidine intermediate (Scheme 1, [2]) mediated by sodium cyanoborohydride in the presence of an equimolar amount of acetic acid yielded the 4-piperidineamine precursor (Scheme 1, [3]) in an excellent yield (91\%). Then, the 4-piperidineamine precursor (Scheme 1, [3]) was acylated using propionyl chloride in the presence of Hunig's base $[N, N$-diisopropylethylamine (DIPEA)] to provide the compound (Scheme 1, [4]). Acid-mediated $\mathrm{N}$-Boc terminal group deprotection followed by acylation with glutaric anhydride in the presence of pyridine led to carboxylic acid (Scheme 1, [6]). Neither step required any further purification. The linker (Gly) ${ }_{4}$ $\mathrm{OtBu}$ (Pravetoni et al., 2012a) was attached in classic fashion using 2-(1H-benzotriazol-1-yl)-1,1,3,3-tetramethyluronium hexafluorophosphate (HBTU) and DIPEA as coupling agents. Last, the tert-butyl ester (Scheme 1, [7]) was hydrolyzed using $20 \%$ of trifluoracetic acid in dichloromethane to afford hapten (Scheme 1, [8]).

Fentanyl Hapten. All commercial reagents and anhydrous solvents were used without further purification or distillation. Analytical 
thin layer chromatography was performed on a MilliporeSigma (Burlington, MA) silica gel $60 \mathrm{~F} 254$ coated plate $(0.25 \mathrm{~mm})$. Plates were visualized by UV light, iodine vapor, or ninhydrin solution. Flash column chromatography was performed on a Thermo Fisher Scientific (Waltham, MA) silica gel (230-400 mesh), unless otherwise noted. NMR $\left({ }^{1} \mathrm{H}\right.$ NMR, $400 \mathrm{MHz} ;{ }^{13} \mathrm{C}$ NMR, $\left.100 \mathrm{MHz}\right)$ spectra were determined on a Bruker (Billerica, MA) 400 spectrometer, unless otherwise noted. Chemical shifts for ${ }^{1} \mathrm{H}$ NMR are reported in parts per million relative to chloroform (7.26 ppm) and coupling constants are reported in Hertz. Chemical shifts are expressed in parts per million, and coupling constants $(J)$ are in Hertz. Peak multiplicities are abbreviated as follows: broad, br; singlet, s; doublet, d; triplet, t; and multiplet, $\mathrm{m}$. Chemical shifts for ${ }^{13} \mathrm{C}$ NMR were reported in parts per million relative to the center line of a triplet at $77.0 \mathrm{ppm}$ for chloroform. Electrospray ionization (ESI) mode mass spectra were recorded on a BrukerBioTOF II Mass Spectrometer (Bruker), and the data were consistent with the considered structures. Elemental analyses for the target compound were performed by M-H-W Laboratories (Phoenix, AZ). Analytical data confirmed that the purity of the products was $\geq 95 \%$.

Tert-Butyl (2-(4-Oxopiperidin-1-yl)Ethyl)Carbamate [2]. 4-Piperidone monohydrate hydrochloride ([1] $2.0 \mathrm{~g}, 13 \mathrm{mmol}$ ) was dissolved in acetonitrile $(40 \mathrm{ml})$ in a $250-\mathrm{ml}$ round-bottom flask equipped with a large stir bar and a condenser. The colorless solution was treated sequentially with potassium carbonate $\left(\mathrm{K}_{2} \mathrm{CO}_{3} ; 3.26 \mathrm{~g}\right.$, $23.6 \mathrm{mmol}$ ) and 2-(Boc-amino)ethylbromide (1.96 ml, $11.8 \mathrm{mmol})$ at ambient temperature. The resulting suspension was vigorously stirred and refluxed at $80^{\circ} \mathrm{C}$ for 8 hours. After 8 hours, the mixture was cooled to ambient temperature, transferred to a separatory funnel and partitioned $\left(\mathrm{CH}_{2} \mathrm{Cl}_{2} / / \mathrm{H}_{2} \mathrm{O}\right)$. The organic phase was washed with brine, saturated in $\mathrm{NaHCO}_{3}(2 \times 100 \mathrm{ml})$, dried over $\mathrm{Na}_{2} \mathrm{SO}_{4}$, and concentrated in vacuo to give a yellow oil. The oily mixture was purified by flash column chromatography (EtOAc/hexanes: 1/1) to give [2] as a light yellow oil $(2.5 \mathrm{~g}, 88 \%) .{ }^{1} \mathrm{H} \mathrm{NMR}\left(400 \mathrm{MHz}, \mathrm{CDCl}_{3}\right) \delta 6.76$ (br, $\left.{ }^{1} \mathrm{H}, \mathrm{NH}\right) ; 3.26\left(\mathrm{t},{ }^{2} \mathrm{H}, \mathrm{J}=7.3 \mathrm{~Hz}\right) ; 2.67-2.59\left(\mathrm{~m},{ }^{4} \mathrm{H}\right) ; 2.46(\mathrm{t}, 2 \mathrm{H}$, $J=7.3 \mathrm{~Hz}) ; 2.22-2.16\left(\mathrm{~m},{ }^{4} \mathrm{H}\right) ; 1.42\left(\mathrm{~s},{ }^{9} \mathrm{H}\right) ;{ }^{13} \mathrm{C} \mathrm{NMR}\left(77 \mathrm{MHz}, \mathrm{C} D C l_{3}\right)$ $\delta 207.1 ; 155.9 ; 79.6 ; 55.3\left({ }^{2} \mathrm{C}\right) ; 53.4 ; 41.2\left({ }^{2} \mathrm{C}\right) ; 38.9 ; 28.4\left({ }^{3} \mathrm{C}\right)$. ESI-timeof-flight (TOF) mass spectrometry (MS) was calculated for $\mathrm{C}_{12} \mathrm{H}_{22} \mathrm{~N}_{2} \mathrm{O}_{3}$ $\left(\mathrm{m} / z, 242.32\right.$; found, $\left.243.43[\mathrm{MH}]^{+}\right)$.

Tert-Butyl (2-(4-(Phenylamino)Piperidin-1-yl)Ethyl)Carbamate [3]. Aniline ( $750 \mu \mathrm{l}, 8.2 \mathrm{mmol})$ was taken up in methylene chloride in a 100-ml round-bottom flask equipped with a stir bar. The light brown solution was placed in an ice bath and treated dropwise with acetic acid $(\mathrm{AcOH} ; 460 \mu \mathrm{l}, 8.2 \mathrm{mmol})$. To the mixture, tert-butyl (2-(4oxopiperidin-1-yl)ethyl)carbamate [2] (2 g, $8.2 \mathrm{mmol}$ ) was added as a solution in methylene chloride, followed by the careful, slow addition of sodium cyanoborohydride $\left(\mathrm{NaBH}_{3} \mathrm{CN} ; 773 \mathrm{mg}, 12.3 \mathrm{mmol}\right)$ in small portions. The reaction mixture was stirred at $80^{\circ} \mathrm{C}$ for 14 hours. After this time, methanol was added to the mixture, and all contents were transferred to a separatory funnel. The mixture was partitioned $\left(\mathrm{CH}_{2} \mathrm{Cl}_{2} /\right.$ saturated $\left.\mathrm{NaHCO}_{3}\right)$. Once neutralized, the organic phase was washed with brine, dried over $\mathrm{Na}_{2} \mathrm{SO}_{4}$, and concentrated in vacuo to give a light brown oil. The oily mixture was purified by flash column chromatography (EtOAc/hexanes: 7/3) to give [3] as a light yellow oil $(2.25 \mathrm{~g}, 86 \%) .{ }^{1} \mathrm{H} \mathrm{NMR}\left(400 \mathrm{MHz}, \mathrm{C} D C l_{3}\right) \delta 7.37\left(\mathrm{~d},{ }^{2} \mathrm{H}, J=7.8 \mathrm{~Hz}\right)$; 7.27-7.25 (m, $\left.{ }^{3} \mathrm{H}\right) ; 6.35$ (br, $\left.{ }^{1} \mathrm{H}, \mathrm{NH}\right) ; 5.21\left(\mathrm{br},{ }^{1} \mathrm{H}, \mathrm{NH}\right) ; 3.84\left(\mathrm{~m},{ }^{1} \mathrm{H}\right)$; 3.77-3.58 (m, $\left.{ }^{4} \mathrm{H}\right) ; 3.21-3.14\left(\mathrm{~m},{ }^{4} \mathrm{H}\right) ; 2.31-2.26\left(\mathrm{~m},{ }^{4} \mathrm{H}\right) ; 1.43\left(\mathrm{~s},{ }^{9} \mathrm{H}\right) ;{ }^{13} \mathrm{C}$ NMR $\left(77 \mathrm{MHz}, \mathrm{C} D C l_{3}\right) \delta 156.7 ; 147.6 ; 129.5\left({ }^{2} \mathrm{C}\right) ; 120.8 ; 113.5\left({ }^{2} \mathrm{C}\right)$; 79.5; 64.3; 53.9; $52.0\left({ }^{2} \mathrm{C}\right) ; 39.7 ; 30.3\left({ }^{2} \mathrm{C}\right) ; 26.8\left({ }^{3} \mathrm{C}\right)$. ESI-TOF MS was calculated for $\mathrm{C}_{18} \mathrm{H}_{29} \mathrm{~N}_{3} \mathrm{O}_{2}\left(\mathrm{~m} / z, 319.23\right.$; found, $\left.320.17[\mathrm{MH}]^{+}\right)$.

Tert-Butyl (2-(4-(N-Phenylpropionamido)Piperidin-1-yl)Ethyl) Carbamate [4]. Compound [3] (1.5 g, $4.7 \mathrm{mmol})$ was dissolved in methylene chloride in a 100-ml round-bottom flask equipped with a small stir bar and was treated with DIPEA $(1.64 \mathrm{ml}, 9.4 \mathrm{mmol})$. The solution was cooled with an ice bath and treated dropwise with propionyl chloride $(0.81 \mathrm{ml}, 9.4 \mathrm{mmol})$. The resulting mixture was stirred for 2 hours at ambient temperature. The mixture was transferred to a separatory funnel and partitioned $\left(\mathrm{CH}_{2} \mathrm{Cl}_{2} / / \mathrm{H}_{2} \mathrm{O}\right)$. The organic phase was washed with brine, saturated in $\mathrm{NaHCO}_{3}$, dried over anhydrous $\mathrm{Na}_{2} \mathrm{SO}_{4}$, and evaporated in vacuo to give a yellow oil that was purified by flash column chromatography (EtOAc/hexanes: $4 / 6)$ to furnish [4] as a light yellow oil $(1.68 \mathrm{~g}, 95 \%) .{ }^{1} \mathrm{H} \mathrm{NMR}(400 \mathrm{MHz}$, $\left.\mathrm{CDCl}_{3}\right) \delta 7.40-7.27\left(\mathrm{~m},{ }^{3} \mathrm{H}\right) ; 7.26(\mathrm{~d}, 2 \mathrm{H}, J=7.8 \mathrm{~Hz}) ; 4.72\left(\mathrm{~m},{ }^{1} \mathrm{H}\right) ; 3.98$ $(\mathrm{t}, 2 \mathrm{H}, \mathrm{J}=7.1 \mathrm{~Hz}) ; 3.27-3.17\left(\mathrm{~m},{ }^{4} \mathrm{H}\right) ; 2.82-2.74\left(\mathrm{~m},{ }^{4} \mathrm{H}\right) ; 2.15-2.08$ $\left(\mathrm{m},{ }^{4} \mathrm{H}\right) ; 1.40\left(\mathrm{~s},{ }^{9} \mathrm{H}\right) ; 1.01\left(\mathrm{t},{ }^{3} \mathrm{H}, J=7.1 \mathrm{~Hz}\right) ;{ }^{13} \mathrm{C} \mathrm{NMR}\left(77 \mathrm{MHz}, \mathrm{C} D C l_{3}\right)$ $\delta 174.6 ; 155.9 ; 137.9 ; 128.3\left({ }^{2} \mathrm{C}\right) ; 128.0 ; 127.5\left({ }^{2} \mathrm{C}\right) ; 81.5 ; 62.5 ; 53.9 ; 53.4$ $\left({ }^{2} \mathrm{C}\right) ; 40.1 ; 28.2 ; 26.8\left({ }^{3} \mathrm{C}\right) ; 25.9\left({ }^{2} \mathrm{C}\right) ; 10.3$. ESI-TOF MS was calculated for $\mathrm{C}_{21} \mathrm{H}_{33} \mathrm{~N}_{3} \mathrm{O}_{3}\left(\mathrm{~m} / z, 319.23\right.$; found, $\left.320.17[\mathrm{MH}]^{+}\right)$.

$\boldsymbol{N}$-(1-(2-Aminoethyl)Piperidin-4-yl)- $\boldsymbol{N}$-Phenylpropionamide [5]. Trifluoroacetic acid (TFA; 20\% volume) was added to a solution of compound [4] (1 g, $3.1 \mathrm{mmol})$ in dichloromethane (40 ml). The resultant solution was stirred at room temperature. Upon complete disappearance of starting material, the solvent was removed under vacuum. The crude reaction mixture was coevaporated with large volumes of dichloromethane several times to yield a white solid that was placed under vacuum overnight. The resulting white solid (1.45 g, quantitative) was used without further purification. ${ }^{1} \mathrm{H}$ NMR $\left(400 \mathrm{MHz}, \mathrm{C} D C l_{3}\right) \delta 12.2\left(\mathrm{br},{ }^{1} \mathrm{H}\right) ; 7.37-7.29\left(\mathrm{~m},{ }^{3} \mathrm{H}\right) ; 7.03\left(\mathrm{~d},{ }^{2} \mathrm{H}, J=\right.$ $7.8 \mathrm{~Hz}) ; 4.62\left(\mathrm{~m},{ }^{1} \mathrm{H}\right) ; 3.83\left(\mathrm{t},{ }^{2} \mathrm{H}, \mathrm{J}=7.1 \mathrm{~Hz}\right) ; 3.18-3.05\left(\mathrm{~m},{ }^{4} \mathrm{H}\right)$; $2.75-2.62\left(\mathrm{~m},{ }^{4} \mathrm{H}\right) ; 2.15-2.08\left(\mathrm{~m},{ }^{4} \mathrm{H}\right) ; 0.98\left(\mathrm{t},{ }^{3} \mathrm{H}, J=7.1 \mathrm{~Hz}\right) ;{ }^{13} \mathrm{C}$ NMR $\left(77 \mathrm{MHz}, \mathrm{CDCl}_{3}\right) \delta 177.3 ; 161.4 ; 159.3 ; 136.2 ; 126.2\left({ }^{2} \mathrm{C}\right) ; 126.1 ; 125.9$ $\left({ }^{2} \mathrm{C}\right) ; 113.2 ; 112.9 ; 85.7 ; 62.3 ; 54.2 ; 53.4\left({ }^{2} \mathrm{C}\right) ; 41.2 ; 27.2 ; 23.9\left({ }^{2} \mathrm{C}\right) ; 10.3$. ESI-TOF MS calculated for $\mathrm{C}_{20} \mathrm{H}_{27} \mathrm{~F}_{6} \mathrm{~N}_{3} \mathrm{O}_{5}(\mathrm{~m} / z, 503.19$; found, 377.25 $\left.[\mathrm{MH}-\mathrm{TFA}]^{+}, 276.33[\mathrm{MH}-2 \mathrm{xTFA}]^{+}\right)$.

\section{5-Oxo-5-((2-(4-(N-Phenylpropionamido)Piperidin-1-yl)}

Ethyl)Amino)Pentanoic Acid [6]. To a solution of amine [5] (1 g, $2 \mathrm{mmol})$ dissolved in dichloromethane with pyridine $(0.64 \mathrm{ml}, 6 \mathrm{mmol})$, and glutaric anhydride $(228 \mathrm{mg}, 2 \mathrm{mmol}$ ) was added dropwise. The mixture was stirred at room temperature overnight. After the disappearance of the starting material, the solvent was concentrated to dryness; the residue was coevaporated with toluene $(3 \times)$. The mixture was transferred to a separatory funnel and partitioned $\left(\mathrm{CH}_{2} \mathrm{Cl}_{2} / / \mathrm{H}_{2} \mathrm{O}\right)$. The organic phase was washed with brine, saturated in $\mathrm{NaHCO}_{3}$, dried over anhydrous $\mathrm{Na}_{2} \mathrm{SO}_{4}$, and evaporated in vacuo to give [6] as a white solid (780 mg, quantitative). Compound [6] was used without further purification. ${ }^{1} \mathrm{H} \mathrm{NMR}\left(400 \mathrm{MHz}, \mathrm{C} D C l_{3}\right) \delta 7.35-7.31$ $\left(\mathrm{m},{ }^{3} \mathrm{H}\right) ; 7.02\left(\mathrm{~d},{ }^{2} \mathrm{H}, J=7.8 \mathrm{~Hz}\right) ; 4.79\left(\mathrm{~m},{ }^{1} \mathrm{H}\right) ; 4.02\left(\mathrm{t},{ }^{2} \mathrm{H}, \mathrm{J}=7.1 \mathrm{~Hz}\right)$; 4.57-4.52 (m, $\left.{ }^{2} \mathrm{H}\right) ; 2.91-2.85\left(\mathrm{~m},{ }^{2} \mathrm{H}\right) ; 2.62-2.51\left(\mathrm{~m},{ }^{4} \mathrm{H}\right) ; 2.25-2.13$ $\left(\mathrm{m},{ }^{2} \mathrm{H}\right) ; 1.99-1.75\left(\mathrm{~m},{ }^{8} \mathrm{H}\right) ; 0.98\left(\mathrm{t},{ }^{3} \mathrm{H}, J=7.1 \mathrm{~Hz}\right) ;{ }^{13} \mathrm{C} \mathrm{NMR}(77 \mathrm{MHz}$, $\left.\mathrm{C} D C l_{3}\right) \delta 178.4 ; 174.6 ; 172.6 ; 137.9 ; 128.9\left({ }^{2} \mathrm{C}\right) ; 128.1 ; 127.5\left({ }^{2} \mathrm{C}\right) ; 83.5$; $59.1 ; 52.0\left({ }^{2} \mathrm{C}\right) ; 39.2 ; 35.6 ; 32.3 ; 28.2 ; 27.6\left({ }^{2} \mathrm{C}\right) ; 20.3 ; 10.2$. ESI-TOF MS was calculated for $\mathrm{C}_{21} \mathrm{H}_{31} \mathrm{~N}_{3} \mathrm{O}_{4}\left(\mathrm{~m} / z, 389.23\right.$; found, $\left.390.21[\mathrm{MH}]^{+}\right)$.

Tert-Butyl (5-Oxo-5-((2-(4-(N-Phenylpropionamido)Piperidin1-yl)Ethyl)Amino)Pentanoyl)Glycylglycylglycylglycinate [7]. The carboxylic acid [6] (500 mg, $1.28 \mathrm{mmol}$ ) was dissolved in dichloromethane, followed by the subsequent addition of HBTU $(729 \mathrm{mg}$, $1.92 \mathrm{mmol}$ ) and the appropriate amine $(\mathrm{Gly})_{4}$-OtBu (Pravetoni et al., 2012a) (387 mg, $1.28 \mathrm{mmol}$ ). DIPEA (403 $\mu \mathrm{l}, 2.31 \mathrm{mmol}$ ) was then added to the mixture. The solution was stirred overnight at room temperature. The mixture was transferred to a separatory funnel and partitioned $\left(\mathrm{CH}_{2} \mathrm{Cl}_{2} / / \mathrm{H}_{2} \mathrm{O}\right)$. The organic phase was washed with brine, saturated in $\mathrm{NaHCO}_{3}$, dried over anhydrous $\mathrm{Na}_{2} \mathrm{SO}_{4}$, and evaporated in vacuo. The resulting mixture was purified by $\mathrm{SiO}_{2}$ flash column chromatography (EtOAc/hexanes: 6/4) to provide [7] as a light yellow oil $(637 \mathrm{mg}, 74 \%) .{ }^{1} \mathrm{H} \mathrm{NMR}\left(400 \mathrm{MHz}, \mathrm{C} D C l_{3}\right) \delta$ $7.41-7.39\left(\mathrm{~m},{ }^{3} \mathrm{H}\right) ; 7.08\left(\mathrm{~d},{ }^{2} \mathrm{H}, J=7.9 \mathrm{~Hz}\right) ; 6.13\left(\mathrm{br},{ }^{1} \mathrm{H}, \mathrm{NH}\right) ; 4.62(\mathrm{~m}$, $\left.{ }^{1} \mathrm{H}\right) ; 3.71-3.65\left(\mathrm{~m},{ }^{10} \mathrm{H}\right) ; 3.30-3.26\left(\mathrm{~m},{ }^{2} \mathrm{H}\right) ; 3.00-2.98\left(\mathrm{~m},{ }^{2} \mathrm{H}\right)$; $2.55-2.49\left(\mathrm{~m},{ }^{2} \mathrm{H}\right) ; 2.32-2.15\left(\mathrm{~m},{ }^{6} \mathrm{H}\right) ; 1.93-1.80\left(\mathrm{~m},{ }^{6} \mathrm{H}\right) ; 1.43(\mathrm{~s}$, $\left.{ }^{9} \mathrm{H}\right) ; 0.98\left(\mathrm{t},{ }^{3} \mathrm{H}, J=7.1 \mathrm{~Hz}\right) ;{ }^{13} \mathrm{C} \mathrm{NMR}\left(77 \mathrm{MHz}, \mathrm{C} D C l_{3}\right) \delta 177.9$; $174.8 ; 172.5 ; 171.0\left({ }^{3} \mathrm{C}\right) ; 169.5 ; 137.8 ; 128.4\left({ }^{2} \mathrm{C}\right) ; 128.2 ; 127.6\left({ }^{2} \mathrm{C}\right)$; $83.3 ; 81.8 ; 59.1 ; 52.1\left({ }^{2} \mathrm{C}\right) ; 42.4 ; 42.7 ; 41.0 ; 39.6 ; 35.5 ; 34.6 ; 28.7\left({ }^{3} \mathrm{C}\right)$; $27.5\left({ }^{2} \mathrm{C}\right) ; 22.2 ; 10.1$. ESI-TOF MS calculated for $\mathrm{C}_{33} \mathrm{H}_{51} \mathrm{~N}_{7} \mathrm{O}_{8}(m / z$, 673.38; found, $\left.674.47[\mathrm{MH}]^{+}\right)$.

(5-Oxo-5-((2-(4-(N-Phenylpropionamido)Piperidin-1-yl)Ethyl) Amino)Pentanoyl)Glycylglycylglycylglycine [8]. TFA (1 ml) was added to a solution of compound [7] (300 mg, $0.47 \mathrm{mmol})$ in dichloromethane $(4 \mathrm{ml})$. The mixture was stirred at room temperature 
overnight. Upon complete disappearance of the starting material, the solvent was removed under vacuum. The residue was redissolved in dichloromethane and evaporated again. This operation was repeated twice to afford a pale yellow paste that was purified by $\mathrm{SiO}_{2}$ flash column chromatography $\left(\mathrm{MeOH} / \mathrm{CH}_{2} \mathrm{Cl}_{2}: 2 / 98\right)$ to give compound [8] as a white solid (266 mg, 92\%). ${ }^{1} \mathrm{H}$ NMR $\left(400 \mathrm{MHz}^{\mathrm{C}} \mathrm{CCl}_{3}\right) \delta 7.39-7.36$ $\left(\mathrm{m},{ }^{3} \mathrm{H}\right) ; 7.02\left(\mathrm{~d},{ }^{2} \mathrm{H}, J=7.9 \mathrm{~Hz}\right) ; 4.59\left(\mathrm{~m},{ }^{1} \mathrm{H}\right) ; 3.69-3.62\left(\mathrm{~m},{ }^{10} \mathrm{H}\right)$; 3.21-3.18 (m, $\left.{ }^{2} \mathrm{H}\right) ; 2.98-2.92\left(\mathrm{~m},{ }^{2} \mathrm{H}\right) ; 2.47-2.42\left(\mathrm{~m},{ }^{2} \mathrm{H}\right) ; 2.29-2.16(\mathrm{~m}$, $\left.{ }^{6} \mathrm{H}\right) ; 1.91-1.82\left(\mathrm{~m},{ }^{6} \mathrm{H}\right) ; 0.97\left(\mathrm{t},{ }^{3} \mathrm{H}, J=7.1 \mathrm{~Hz}\right) ;{ }^{13} \mathrm{C}$ NMR $(77 \mathrm{MHz}$, $\left.\mathrm{CDCl}_{3}\right) \delta 178.1 ; 174.6 ; 174.2 ; 172.6 ; 169.2\left({ }^{3} \mathrm{C}\right) ; 137.9 ; 128.6\left({ }^{2} \mathrm{C}\right) ; 128.4$; $127.5\left({ }^{2} \mathrm{C}\right) ; 83.4 ; 59.8 ; 53.3\left({ }^{2} \mathrm{C}\right) ; 42.7 ; 42.9 ; 41.3 ; 39.7 ; 35.3 ; 34.7 ; 27.6$ $\left({ }^{2} \mathrm{C}\right)$; 22.5 ; 10.3. ESI-TOF MS was calculated for $\mathrm{C}_{29} \mathrm{H}_{43} \mathrm{~N}_{7} \mathrm{O}_{8}(\mathrm{~m} / z$, 617.32; found, $618.31[\mathrm{MH}]^{+}$). Analytical calculation for $\mathrm{C}_{29} \mathrm{H}_{43} \mathrm{~N}_{7} \mathrm{O}_{8}$ : C, 56.39; H, 7.02; N, 15.87; found: C, 56.34; H, 6.99; N, 15.91 .

\section{Vaccines}

The F (Fig. 1B) was conjugated through carbodiimide (EDAC; Sigma-Aldrich, St. Louis, MO) chemistry as previously described for other opioid-based haptens (Pravetoni et al., 2012a,b). Briefly, $5 \mathrm{mM}$ hapten was reacted with a $52 \mathrm{mM}$ concentration of EDAC in $0.1 \mathrm{M}$ MES (4-morpholineethanesulfonic acid) buffer at $\mathrm{pH} 4.5$, and stirred for 5 minutes at room temperature. Bovine serum albumin (BSA), ovalbumin (OVA), KLH, or sKLH was then added to the reaction mixture in amounts of $2.8,1.9,2.8$, and $2.8 \mathrm{mg}$, respectively, in a final volume of $1 \mathrm{ml}$, and stirred for 3 hours at room temperature as described previously (Pravetoni et al., 2012a). Bioconjugation efficacy was indirectly measured by assessing the haptenation ratio of F-BSA by comparing the molecular weight of the unconjugated and conjugated BSA by matrix-assisted laser desorption/ionization (MALDI)TOF. Conditions optimized for F-BSA led to a haptenation ratio of 8 . Haptenation ratios were not determined for KLH because its molecular weight is too large to be measured by MALDI-TOF.

\section{Drugs}

Fentanyl, oxycodone, and heroin were obtained through the National Institute on Drug Abuse Drug Supply Program (Bethesda, MD) or Sigma-Aldrich. Drug doses and concentrations are expressed as the weight of the base.

\section{Brain and Serum Fentanyl Concentration}

Fentanyl concentrations were measured by gas chromatography MS using a modified procedure (Huynh et al., 2005). Briefly, trunk blood was collected and centrifuged after experimentation at $3100 \mathrm{~g}$ for 3 minutes at $4^{\circ} \mathrm{C}$. Internal standard (D5-fentanyl; $50 \mu \mathrm{l}$ of $1 \mu \mathrm{g} / \mathrm{ml}$ ) was added to all serum and standard samples. Then, $0.15 \mathrm{ml}$ of $1.0 \mathrm{M}$ $\mathrm{NaOH}$ and $3.5 \mathrm{ml}$ of $\mathrm{n}$-heptane with $3 \% 2$-butanol was added to 0.5 -ml serum samples. Samples were capped and rotated at approximately 15 rpm for 30 minutes on an orbital shaker (Orbitron Rotator II, Model 260250; Boekel Scientific, Feasterville, PA) and then centrifuged for 5 minutes at $1500 \mathrm{~g}$. The lower aqueous phase was frozen using a mixture of dry ice and acetone for 10 minutes. The solvent layer was transferred and placed on an N-Evap at $45^{\circ} \mathrm{C}$ until the solvent was completely evaporated. The solvent was reconstituted in $50 \mu \mathrm{l}$ of ethyl acetate, briefly vortexed, and then centrifuged for 5 minutes at $1500 \mathrm{~g}$. Samples were injected into the gas chromatograph/mass spectrometer for analysis.

\section{Antibody Characterization}

Antibody Titers. Fentanyl-specific serum IgG antibody titers were measured as previously described for other hapten conjugates (Raleigh et al., 2013, 2017). Briefly, F conjugated to OVA (F-OVA) was used as the coating antigen for mouse studies and $\mathrm{F}$ conjugated to BSA (F-BSA) was used as the coating antigen for rat studies. Coating antigen was diluted in a $0.05 \mathrm{M}$ carbonite buffer ( $\mathrm{pH}$ 9.6), coated onto 96-well enzyme-linked immunosorbent assay plates (Jackson ImmunoResearch,
West Grove, PA), and stored overnight at $4^{\circ} \mathrm{C}$. Plates were blocked with $1 \%$ gelatin in phosphate buffered saline with Tween 20 (PBST) PBST for 1 hour and then stored overnight at $4^{\circ} \mathrm{C}$. The next day, various dilutions of sera in 0.05 M PBST were added to the wells and plates, and were incubated for 2 hours at room temperature. After washing the plates, Fc-specific goat anti-rat or anti-mouse IgG coupled to horseradish peroxidase (Jackson ImmunoResearch), were added and incubated at overnight at $4^{\circ} \mathrm{C}$. $O$-phenylenediamine was used (SIGMAFAST tablet set; Sigma Life Sciences, St. Louis, MO) as the reaction substrate. After 30 minutes of incubation, $2 \%$ oxalic acid was added to stop the enzymatic reaction. Plates were read at $492 \mathrm{~nm}$ on a BioTek PowerWave XS (BioTek Instruments Inc., Winooski, VT).

Estimated Minimum Antibody Concentrations. The minimal fentanyl-specific antibody concentrations present in serum were estimated by assuming that the difference in serum fentanyl concentration in vaccinated and control rats represents the fentanyl retained in serum by the binding capacity contributed by antibody. This value was calculated by subtracting the mean control vaccine group serum fentanyl concentration from the individual serum fentanyl concentration from each vaccinated rat and multiplying by the molecular weight of IgG (150,000 Da) divided by two binding sites per IgG.

Stoichiometry. The total number of moles per kilogram of opioidspecific IgG in rats vaccinated with F-KLH or F-sKLH in Experiments 2 and 4 was calculated as the product of the estimated antibody concentration in serum and the reported IgG volume of distribution $(131 \mathrm{ml} / \mathrm{kg})$ in rats (Bazin-Redureau et al., 1997; Pravetoni et al., 2012a).

\section{Experiment 1: Effect of F-KLH on Opioid Distribution and Antinociception after Single Fentanyl Challenge in Mice}

Male BALB/c mice (Envigo, Madison, WI), 5 to 6 weeks old, were housed in groups of four under a standard 12-hour light/dark cycle. Groups of eight mice were immunized subcutaneously with F-KLH or control KLH vaccine containing $25 \mu \mathrm{g}$ of immunogen and $0.5 \mathrm{mg}$ of aluminum hydroxide (Alhydrogel; Invitrogen, San Diego, CA). Vaccine was administered subcutaneously on days 0,14 , and 28 . On day 35 , blood was collected via submandibular bleeding for antibody characterization. On day 42 , baseline antinociception was assessed by placing mice on a $54^{\circ} \mathrm{C}$ hotplate and measuring the latency to respond, which was defined as the time until a response of hindpaw lick or jumping (Pravetoni et al., 2012a). Testing was terminated at 60 seconds to avoid tissue damage. Mice received a $0.05 \mathrm{mg} / \mathrm{kg}$, s.c., dose of fentanyl. This dose was chosen because it elicited submaximal latency to respond on the hotplate in a pilot study. Thirty minutes after dosing, mice were placed on the hotplate again to measure the latency to respond. The percentage maximum possible effect (\%MPE) was calculated as the post-test latency minus the pretest latency divided by the maximum time ( 60 seconds) minus the pretest latency times 100. Immediately after hotplate testing, mice were anesthetized with isoflurane, and blood and brain samples were collected to assess drug levels.

\section{Experiment 2: Efficacy and Selectivity of F-KLH on Opioid Distribution and Antinociception in Rats Challenged with Fentanyl, Heroin, and Oxycodone}

Male Holtzman rats (Envigo) weighing 200-225 g were double housed with a standard 12-hour light/dark cycle. Groups of 12 rats were immunized subcutaneously with F-KLH or control KLH vaccine containing $25 \mu \mathrm{g}$ of immunogen and $0.5 \mathrm{mg}$ of aluminum hydroxide. Vaccine was administered intramuscularly on days 0,21 , and 42 . On day 49 , blood was collected via tail vein for antibody characterization. Hotplate testing was identical to that in Experiment 1, except that rats received a $0.035 \mathrm{mg} / \mathrm{kg}$, s.c., dose of fentanyl. This dose was chosen because it elicited submaximal latency to respond on the hotplate in a pilot study. On day 51, KLH-immunized and F-KLH-immunized rats were split into two groups: half ( $n=6$ for $\mathrm{KLH}$-treated rats; $n=6$ for 
F-KLH-treated rats) received $1 \mathrm{mg} / \mathrm{kg}$, s.c., heroin, and the other half ( $n=6$ for KLH-treated rats; $n=6$ for F-KLH-treated rats) received $2.25 \mathrm{mg} / \mathrm{kg}$, s.c., oxycodone and were tested on the hotplate, as in Experiment 1. These doses were chosen because they produce significant antinociception and have previously been used to test heroin and oxycodone vaccine efficacy in rats (Pravetoni et al., 2012a, 2013; Raleigh et al., 2013). On day 58 , rats were given a $0.05 \mathrm{mg} / \mathrm{kg}$, i.v., infusion of fentanyl for 1 minute, and blood and brain samples were collected 4 minutes later. The intravenous route was chosen, in contrast to the subcutaneous route commonly used for antinociception, because it provides the most rigorous challenge with regard to route, and because it corresponds to how it is most commonly encountered as an adulterant. The dose was chosen because it was a large fentanyl dose capable of testing vaccine efficacy and because fentanyl levels in serum and brain in rats at this intravenous dose were already well described (Hug and Murphy, 1981).

\section{Experiment 3: Fentanyl-Induced Antinociception and Respiratory Depression after Repeated Fentanyl Challenges in Rats}

Sprague-Dawley rats were used in Experiments 3 and 4 because Holtzman rats became temporarily unavailable. Male SpragueDawley rats (Envigo) weighing 200-225 g were double housed with a standard 12-hour light/dark cycle. To determine a fentanyl dose range that produced a wide range of antinociception and respiratory depression, eight rats were tested on the hotplate and oximeter after successive fentanyl subcutaneous doses. Baseline antinociception (prior to fentanyl administration) was assessed. Immediately after the hotplate test, rats were placed in a $12 \times 12$ inch enclosed chamber to prevent escape and a MouseOx (STARR Life Sciences Corp., Oakmont, PA) arterial oxygen saturation $\left(\mathrm{SaO}_{2}\right)$ monitor was placed via neck collar for at least 1 minute to ensure stable readings were obtained, and baseline $\mathrm{SaO}_{2}$ was measured as described previously (Raleigh et al., 2017). $\mathrm{SaO}_{2}$, breath rate, and heart rates were recorded as the mean of the last 10 seconds, which correspond to 10 measurements. Rats then received fentanyl every 17 minutes subcutaneously so that their cumulative fentanyl doses at successive intervals were $12.5,25,50$, and $100 \mu \mathrm{g} / \mathrm{kg}$. Fifteen minutes after each fentanyl dose, antinociception and $\mathrm{SaO}_{2}$ were again measured; this accounted for 2 minutes, resulting in the 17-minute fentanyl dosing interval. Heart rate was obtained from the oximeter. Rats received $0.1 \mathrm{mg} / \mathrm{kg}$, s.c., naloxone immediately after the final antinociception, and $\mathrm{SaO}_{2}$ measures were obtained. The naloxone dose was chosen based on previous data (Raleigh et al., 2017) and is comparable to the maximum recommended dose (Wong, 2012). Antinociception and cutaneous $\mathrm{SaO}_{2}$ were again measured 15 minutes after naloxone administration. Rats were awake throughout hotplate and oximeter testing.

\section{Experiment 4: Efficacy of F-sKLH on Opioid Distribution, Antinociception, and Respiratory Depressive Effects after Repeated Fentanyl Challenges in Rats}

Male Sprague-Dawley rats (Envigo) weighing 200-225 g were double housed with a standard 12-hour standard light/dark cycle. Groups of eight rats were immunized intramuscularly with F-sKLH or control sKLH vaccine containing $25 \mu \mathrm{g}$ of immunogen and $0.5 \mathrm{mg}$ of aluminum hydroxide on days $0,21,42$, and 63 . On day 70 , blood was collected via tail vein for antibody characterization. On day 77, rats were tested on the hotplate and oximeter using the same protocol as in Experiment 3. Blood and brain samples were collected at the end of the experiment to measure fentanyl concentrations in these tissues.

\section{Statistical Analysis}

Fentanyl-specific serum antibody titers, opioid levels, and hotplate antinociception for Experiments 1 and 2 were compared between groups using unpaired $t$ tests with Welsh's correction. For Experiment 3 , latency to respond in the hotplate nociception test and $\mathrm{SaO}_{2}$ were compared using a repeated-measures one-way analysis of variance using Dunnett's multiple-comparison test. For Experiment 4, the latency to respond in the hotplate nociception test and $\mathrm{SaO}_{2}$ were compared between groups over time by two-way analysis of variance using Sidak's multiple-comparisons test, whereas within-group comparisons were performed using Dunnett's multiple-comparison test. The $\mathrm{ED}_{50}$ for fentanyl on the antinociceptive hotplate test was performed using nonlinear regression analysis using the model [Agonist] versus response - Variable slope (four parameters) with the ceiling parameter set as a constant equal to 60 seconds (maximal latency to respond). The $\mathrm{ED}_{50}$ for the percentage of $\mathrm{SaO}_{2}$ and breath rate could not be measured because minimum and maximum values could not be established. All statistics were performed using Prism (version 8.0a.91; GraphPad, San Diego, CA).

\section{Results}

Experiment 1: Efficacy of F-KLH on Opioid Distribution and Antinociception after Single Subcutaneous Injection of Fentanyl in Mice. Mice vaccinated with F-KLH had $92 \pm 62 \times 10^{3}$ (mean \pm S.D.) fentanyl-specific antibody titers. The estimated minimum antibody concentrations were $5.3 \pm 1.5 \mu \mathrm{g} / \mathrm{ml}$. Because of the manner in which this minimum concentration was estimated (from the concentration of fentanyl retained in serum by antibody), the actual antibody concentration may have been higher. F-KLH vaccination significantly reduced fentanyl-induced antinociceptive effects on the hotplate by $60 \%$ compared with controls (Fig. 2A) $(P<0.01)$. Serum fentanyl concentrations were significantly increased in F-KLH-vaccinated mice compared with controls (Fig. 2B) $(P<0.001)$.

Experiment 2: Efficacy of F-KLH on Opioid Distribution and Antinociception after Single Subcutaneous Injection of Fentanyl in Rats. Rats vaccinated with F-KLH had $9.0 \pm 4.4 \times 10^{3}$ fentanyl-specific antibody titers. Estimated minimum antibody concentrations were $18.6 \pm 8.5 \mu \mathrm{g} / \mathrm{ml}$. The molar ratio of the fentanyl dose $(0.035 \mathrm{mg} / \mathrm{kg})$ to the estimated antibody binding sites in F-KLH-vaccinated rats was 3.2. F-KLH vaccination significantly reduced fentanyl-induced antinociceptive effects on the hotplate by $93 \%$ compared with controls (Fig. 3A) $(P<0.05)$. F-KLH vaccination had no effect on heroin- or oxycodone-induced antinociception (Fig. 3, B and C) ( $P=0.64$ and 0.76 , respectively). One week after antinociceptive testing, rats received a 1-minute infusion of $0.05 \mathrm{mg} / \mathrm{kg}$, i.v., fentanyl. The molar ratio of the fentanyl dose $(0.05 \mathrm{mg} / \mathrm{kg})$ to the estimated antibody binding sites in F-KLH-vaccinated rats was 4.6. Serum fentanyl concentrations were significantly increased (Fig. 3D) $(P<0.001)$, and brain fentanyl concentrations were decreased by $30 \%$ (Fig. $3 \mathrm{E})(P<0.05)$ compared with controls.

Experiment 3: Fentanyl-Induced Antinociception and Respiratory Depression after Cumulative Subcutaneous Fentanyl Dosing in Rats. Latency to respond on the hotplate was significantly increased after the 25,50 , and $100 \mu \mathrm{g} / \mathrm{kg}$ cumulative doses (Fig. 4A) $(P<0.001$ at all three doses) compared with baseline latencies. Naloxone returned latencies to respond on the hotplate back to baseline levels. Percent $\mathrm{SaO}_{2}$ levels were significantly reduced after the 50 and $100 \mu \mathrm{g} / \mathrm{kg}$ cumulative doses (Fig. 4B) $(P<0.01$ and $P<0.001$, respectively). Naloxone reversed the $\mathrm{SaO}_{2}$ percentage to baseline values. Heart rate (in beats per minute) was significantly lowered after the 25,50 , and $100 \mu \mathrm{g} / \mathrm{kg}$ cumulative doses (Fig. 4C) $(P<0.01$ at all three doses). Naloxone 

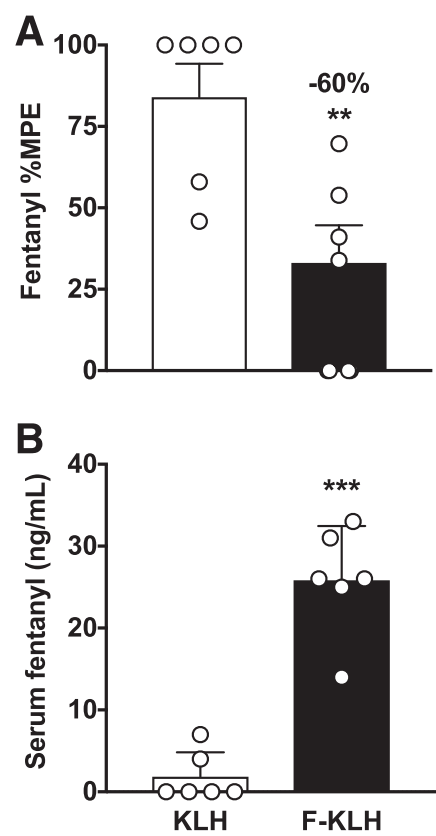

Fig. 2. Experiment 1. F-KLH reduces fentanyl-induced antinociceptive effects and increases serum fentanyl concentrations in mice. Vaccination with F-KLH significantly reduced fentanyl-induced hotplate antinociception by $60 \%$ (mean \pm S.E.M.) (A) and increased serum fentanyl concentrations (mean \pm S.D.) (B) compared with controls 30 minutes after a $0.05 \mathrm{mg} / \mathrm{kg}$, s.c., dose of fentanyl. Numbers above bars represent the percent difference from controls. $* * P<0.01$; $* * * P<0.001$ compared with controls using unpaired $t$ tests with Welsh's correction. $n=6$ /group.

treatment did not reverse the heart rate (in beats per minute) back to baseline $(P<0.001)$.

Experiment 4: Efficacy of F-sKLH on Opioid Distribution, Antinociception, and Respiratory Depressive Effects after Cumulative Subcutaneous Fentanyl Dosing in Rats. Rats vaccinated with $\mathrm{F}$-sKLH had $25 \pm 9.6 \times 10^{3}$ fentanyl-specific antibody titers. Estimated minimum antibody concentrations were $68.2 \pm 46 \mu \mathrm{g} / \mathrm{ml}$. The molar ratio of the fentanyl dose $(0.1 \mathrm{mg} / \mathrm{kg})$ to the estimated antibody binding sites in F-sKLH-vaccinated rats was 2.5. F-sKLH-attenuated fentanyl-induced antinociception by shifting the latency to respond dose-response curve to the right on the hotplate after increasing cumulative doses of fentanyl (Fig. 4D) [vaccination: $\mathrm{F}(1,14)=42.0, P<0.001$; interaction: $\mathrm{F}(5,70)=10.4, P<0.001$; fentanyl dose: $\mathrm{F}(3.35,46.9)=40.9, P<0.001]$. Fentanyl significantly increased the latency to respond after $25 \mu \mathrm{g} / \mathrm{kg}$ in sKLH-vaccinated rats, but only after $100 \mu \mathrm{g} / \mathrm{kg}$ in the F-sKLH group, compared with their baseline values. These values represent an $\mathrm{ED}_{50}$ of $0.02 \pm 0.01 \mu \mathrm{g} / \mathrm{kg}$ in the $\mathrm{sKLH}$ group and $0.08 \pm 0.06 \mu \mathrm{g} / \mathrm{kg}$ in the $\mathrm{F}$-sKLH group, decreasing fentanyl potency by a 5.4-fold shift in the presence of fentanylspecific antibodies. Naloxone completely reversed fentanylinduced antinociception in both groups. F-sKLH significantly reduced fentanyl-induced respiratory depression after the $50 \mu \mathrm{g} / \mathrm{kg}$ fentanyl dose and shifted the percentage of $\mathrm{SaO}_{2}$ dose-response curve rightward (Fig. $4 \mathrm{E}$ ) [vaccination, $\mathrm{F}(1,14)=$ 17.7, $P<0.001$; interaction, $\mathrm{F}(5,70)=9.1, P<0.001$; fentanyl dose, $\mathrm{F}(2,28.1)=49.7, P<0.001]$. Fentanyl significantly decreased the percentage of $\mathrm{SaO}_{2}$ after $25 \mu \mathrm{g} / \mathrm{kg}$ in sKLHvaccinated rats, but only after $100 \mu \mathrm{g} / \mathrm{kg}$ in the F-sKLH group, compared with their baseline values. Naloxone completely reversed the fentanyl-induced percentage of $\mathrm{SaO}_{2}$ in the F-sKLH-vaccinated group, but not in controls $(P<0.05)$. There was no effect of F-sKLH on fentanyl-induced bradycardia (Fig. 4F) [vaccination, $\mathrm{F}(1,14)=2.09, P=0.17$; interaction, $\mathrm{F}(5,70)=3.25, P<0.05$; fentanyl dose, $\mathrm{F}(1.65,23.0)=4.5, P<$ 0.05]. However, fentanyl significantly decreased the heart rate in sKLH-treated rats, but not in F-sKLH-treated rats compared with their baseline $(P<0.05)$. Naloxone completely reversed fentanyl-induced bradycardia in both groups.

Serum fentanyl concentrations were significantly higher in F-sKLH-vaccinated rats compared with controls $(P<0.001)$ after the $100 \mu \mathrm{g} / \mathrm{kg}$, s.c., cumulative fentanyl dose (Fig. 5A). Brain fentanyl concentrations were $73 \%$ lower in F-sKLH-vaccinated rats compared with controls after the $100 \mu \mathrm{g} / \mathrm{kg}$, s.c., cumulative fentanyl dose (Fig. 5B) $(P<0.01)$.

\section{Discussion}

This study found that: 1) F-sKLH attenuated fentanylinduced respiratory depression and antinociception in rats; 2) F-KLH selectively reduced the antinociceptive effects of fentanyl, but not of equianalgesic doses of heroin or oxycodone in vivo; 3) F-sKLH preserved the reversal of fentanyl-induced
A
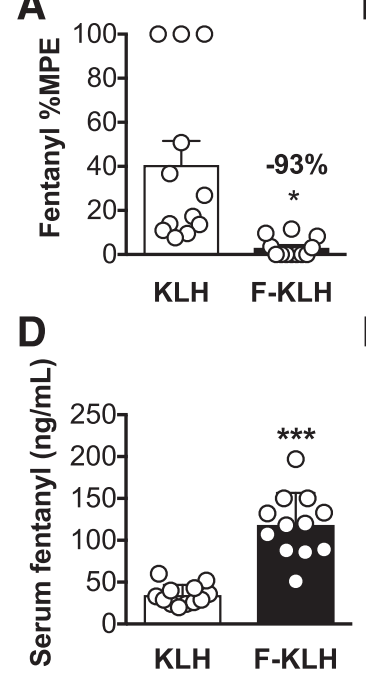

B

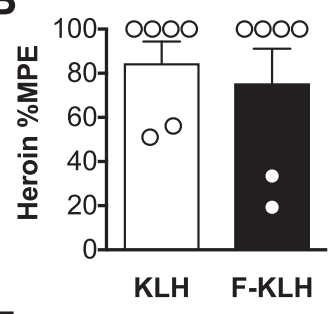

E

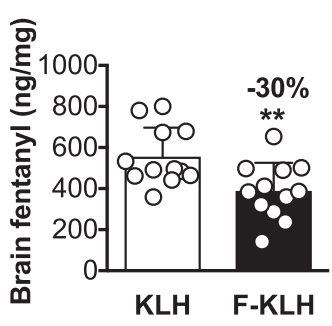

C

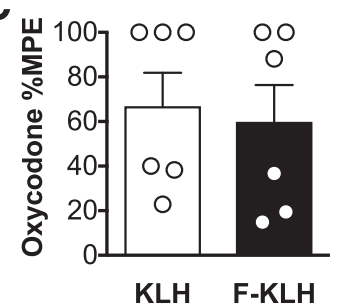

KLH F-KLH

Fig. 3. Experiment 2. Selectivity and pharmacokinetic efficacy of F-KLH in rats. (A) Vaccination with F-KLH significantly reduced fentanyl-induced hotplate antinociception by $93 \% 30$ minutes after a $0.035 \mathrm{mg} / \mathrm{kg}$, s.c., dose of fentanyl. (B and C) F-KLH had no effect on heroin- or oxycodone-induced antinociception 30 minutes after a 1 or $2.25 \mathrm{mg} / \mathrm{kg}$ dose of heroin or oxycodone, respectively. Serum fentanyl concentrations were significantly increased (D) and brain fentanyl concentrations were significantly decreased (E) compared with controls 4 minutes after a 1 -minute $0.05 \mathrm{mg} / \mathrm{kg}$, i.v., infusion of fentanyl. Numbers above bars represent the percentage difference from controls. $* P<0.05$; - * $P<0.01$; *** $P<0.001$ compared with controls. Mean \pm S.D. (D and E), mean \pm S.E.M. (A-C); $n=12 /$ group (A, D, and E) and $n=6 /$ group (B and $\mathrm{C})$. 

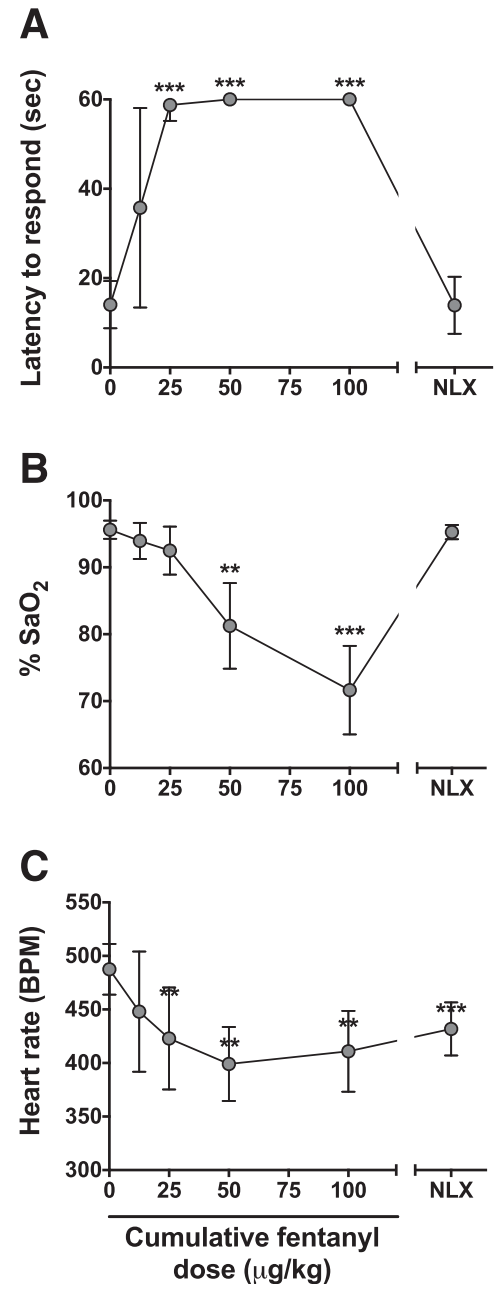
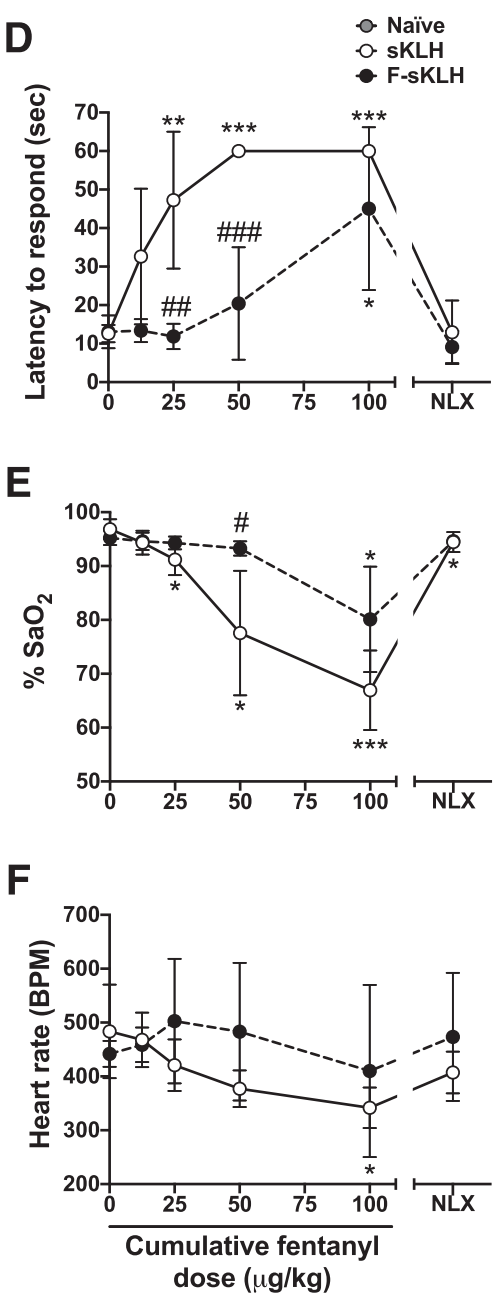

Fig. 4. Experiments 3 and 4. Fentanyl dose-response and F-sKLH effects on hotplate antinociception, respiratory depression, and bradycardia in rats. Fentanyl was administered subcutaneously every 15 minutes at increasing doses in nonimmunized rats, and the doses listed are the cumulative dose received. (A) Effect of fentanyl on hotplate antinociception. Latency to respond is capped at 60 seconds. Naloxone $(0.1 \mathrm{mg} / \mathrm{kg}$, s.c. $)$ was administered 15 minutes after the final fentanyl dose. (B) Effect of fentanyl on respiratory depression measured as $\mathrm{SaO}_{2}$. (C) Effect of fentanyl on heart rate. ${ }^{* *} P<0.01$; $* * * P<0.001$ for the difference between values compared with baseline. (D) Vaccine effects on fentanyl-induced antinociception. (E) Vaccine effects on fentanyl-induced respiratory depression measured as $\mathrm{SaO}_{2}$. (F) Vaccine effects on fentanyl-induced decreases in heart rate. $* P<0.05 ; * * P<0.01 ; * * * P<0.001$ for differences from baseline within groups. $\# P<0.05$; $\# \# P<0.01 ; \# \# \#>0.001$ for the difference between groups at each dose. There were no differences between groups in latency to respond, $\mathrm{SaO}_{2}$, or heart rate after naloxone treatment. Mean \pm S.D.; $n=8$ /group. effects by naloxone; and 4) F-KLH and F-sKLH reduced brain fentanyl levels after the administration of large fentanyl doses. These data demonstrate that a fentanyl vaccine can effectively reduce the effects of fentanyl, including its respiratory depressive effects, when formulated either on the native KLH or its GMP-grade version sKLH, which were both formulated in Food and Drug Administration-approved alum adjuvant and delivered intramuscularly, the most common route of immunization for vaccines.

Fentanyl-induced overdose is characterized by marked respiratory depression, leading to death if respiration is not restored either through reversal (naloxone) or ventilation and oxygenation (Boyer, 2012). Fentanyl-induced respiratory depression may occur at different doses in humans than in rats. In the current study, fentanyl induced respiratory depression at subcutaneous cumulative fentanyl doses above $12.5-25 \mu \mathrm{g} / \mathrm{kg}$ in sKLH-treated and naive rats. In humans, sublingual doses of $800 \mu \mathrm{g}(11 \mu \mathrm{g} / \mathrm{kg}$ in a $70-\mathrm{kg}$ human) caused respiratory depression after 2 hours in all 12 subjects (Lister et al., 2011). In another study (Dahan et al., 2005), apnea was reported in human subjects at an intravenous fentanyl dose as low as $2.9 \mu \mathrm{g} / \mathrm{kg}$, and that prolonged apnea occurred at $7.1 \mu \mathrm{g} / \mathrm{kg}$, leading the investigators to halt using this dose for the remainder of the study. In this same study, respiratory depression measured in rats was reported in the range of 50-90 $\mu \mathrm{g} / \mathrm{kg}$, i.v., and although these doses were infused over a period of 20 minutes to avoid death, suggesting a 10 times higher potency to induce respiratory depression in humans compared with rats.

In this study, F-sKLH attenuated fentanyl-induced respiratory depression up to a cumulative subcutaneous fentanyl dose of $50 \mu \mathrm{g} / \mathrm{kg}$ (four times higher than in the sKLH group), suggesting that fentanyl vaccines can block fentanyl-induced respiratory depression at doses considerably larger than respiratory-depressive doses in human. Another fentanyl vaccine has been shown to reduce the respiratory-depressive effects of fentanyl in dogs after an intravenous dose of $5 \mu \mathrm{g} / \mathrm{kg}$ fentanyl (Torten et al., 1975). However, the dogs in this study were passively immunized and the antibody concentration was not specified. It has not yet been established how effective F-sKLH would be in limiting respiratory depression after intravenous fentanyl doses. The difference seen in vaccine efficacy between these two studies may be due to differences in fentanyl pharmacokinetics in these species, vaccine formulations, or the route of fentanyl administration. Nevertheless, these data suggest that fentanyl vaccines can block the respiratory-depressive effects of fentanyl after various routes of administration.

Hotplate antinociception, a surrogate for addiction-related behaviors because it is mediated in the central nervous system by opioid receptors (Le Bars et al., 2001), was also reduced by vaccination with F-KLH and F-sKLH. F-KLH reduced 

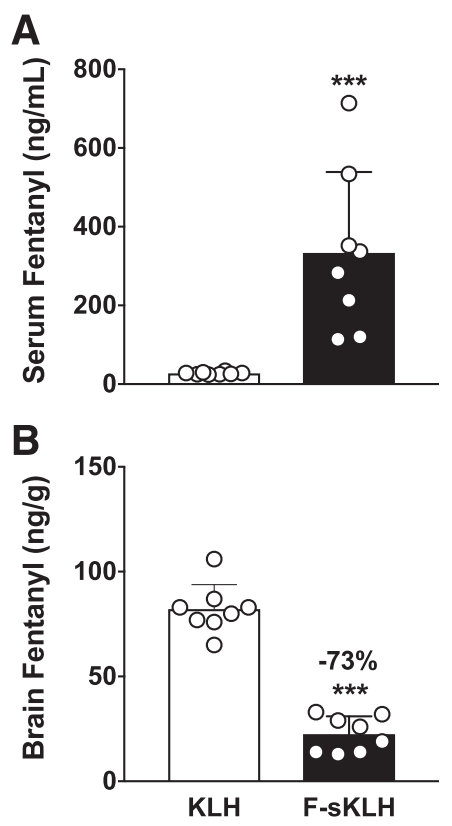

Fig. 5. Experiment 4; F-sKLH alters fentanyl distribution in serum and to the brain. F-sKLH vaccination increases serum (A) and decreases brain fentanyl (B) distribution by $73 \% 30$ minutes after receiving a cumulative $0.1 \mathrm{mg} / \mathrm{kg}$, s.c., fentanyl dose. Numbers above bars represent the percent difference from controls. Mean \pm S.D., ${ }^{* * *} P<0.001$ compared with controls using unpaired $t$ tests with Welch's correction.

fentanyl-induced antinociception by $60 \%$ in mice given $0.05 \mathrm{mg} / \mathrm{kg}$, s.c., fentanyl and $90 \%$ in rats given $0.035 \mathrm{mg} / \mathrm{kg}$, s.c., fentanyl. In Experiment 4, the protective effects of F-sKLH on the hotplate antinociceptive assay extended up until a $100 \mu \mathrm{g} / \mathrm{kg}$, s.c., fentanyl dose (a 5.4-fold shift compared with $\mathrm{KLH}$ controls). Similar findings have been reported in two previous studies. In one study (Torten et al., 1975), a fentanyl vaccine was able to prevent the antinociceptive effect of fentanyl 90 seconds after an intravenous fentanyl dose of $100 \mu \mathrm{g} / \mathrm{kg}$ in mice. In another study (Bremer et al., 2016), a fentanyl vaccine was able to shift the hotplate dose-response curve $\mathrm{ED}_{50}$ value by 24 -fold after cumulative subcutaneous doses of up to $1 \mathrm{mg} / \mathrm{kg}$ fentanyl in mice.

F-KLH blocked the analgesic activity of fentanyl, but not equianalgesic doses of heroin or oxycodone. The antinociceptive potencies $\left(\mathrm{ED}_{50}\right)$ of fentanyl, heroin, and oxycodone $(0.06$, 0.62 , and $1.53 \mathrm{mg} / \mathrm{kg}$, respectively) are significantly different (Peckham and Traynor, 2006), and much larger heroin and oxycodone doses are required to achieve antinociception equivalent to that of fentanyl. In vitro selectivity of antibodies elicited by the fentanyl vaccine was not measured in the current study, but because of the high selectivity of antibodies toward their targeted compound and hapten for other similarly designed opioid vaccines (Pravetoni et al., 2012b; Raleigh et al., 2013, 2014, 2017), cross-reactivity toward heroin and oxycodone is unexpected. These data suggest that a fentanyl vaccine would likely block clinically relevant doses of fentanyl, but not of heroin or oxycodone.

Naloxone is important for reversing fentanyl-induced respiratory depression and overdose (Rzasa Lynn and Galinkin, 2018). Ensuring its effects are maintained is critical when establishing the usefulness of opioid vaccines in humans, especially considering that naloxone may need to be administered more than once due to the high potency of fentanyl (Clarke et al., 2005; Boyer, 2012; Frank and Pollack, 2017; Tomassoni et al., 2017). To this end, it is noteworthy that vaccination with F-KLH in the current study did not interfere with naloxone efficacy for reversing fentanyl respiratory depression.

Both F-KLH and F-sKLH reduced fentanyl distribution to the brain after a large intravenous fentanyl dose and a large cumulative subcutaneous fentanyl dose, respectively, despite
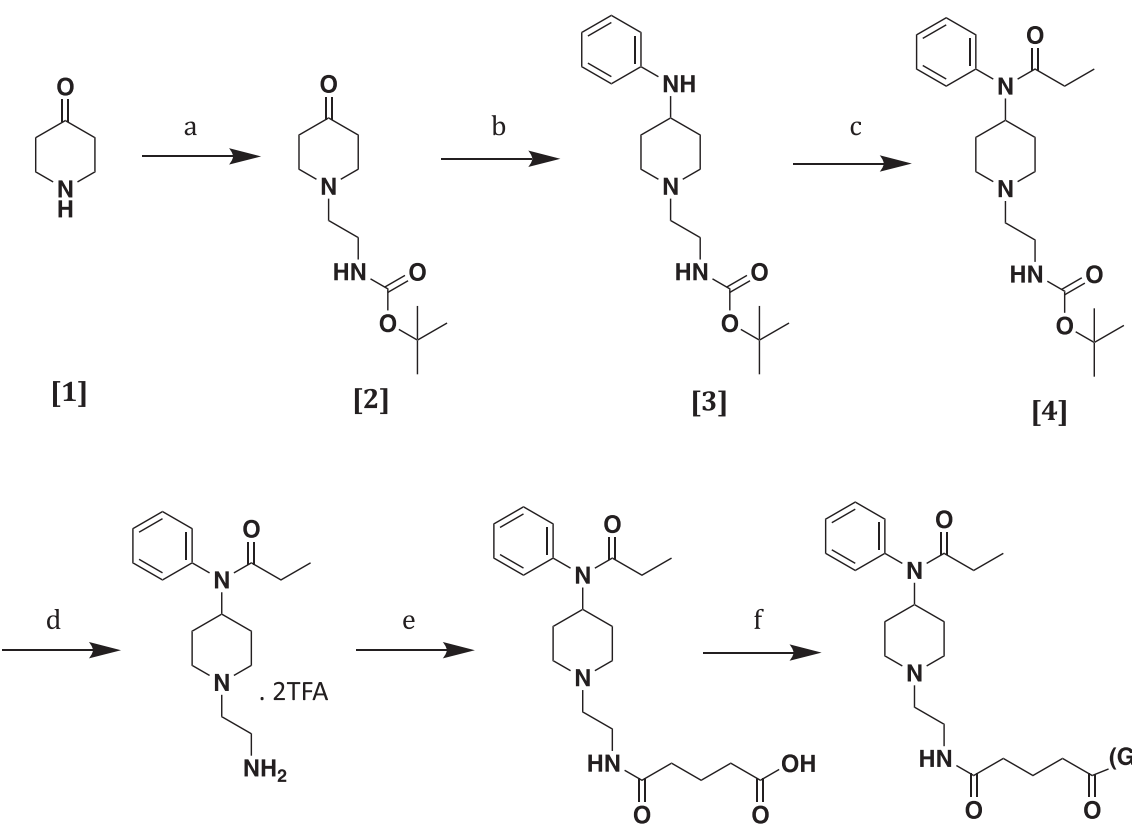

[6]

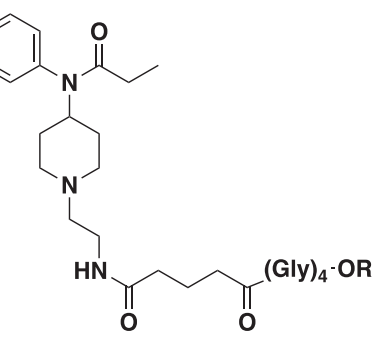

[7]: $\mathrm{R}=\mathrm{tBu}$

[8]: $\mathrm{R}=\mathrm{H}$

Scheme 1. Synthetic pathway to hapten [8]. (a-g) Reactants: 2-(Boc-amino)ethylbromide, $\mathrm{K}_{2} \mathrm{CO}_{3}$, acetonitrile, $80^{\circ} \mathrm{C}$, $88 \%$ (a); aniline, $\mathrm{AcOH}, \mathrm{NaBH}_{3} \mathrm{CN}, \mathrm{CH}_{2} \mathrm{Cl}_{2}$, $80^{\circ} \mathrm{C}, 86 \%$ (b); propionyl chloride, DIPEA, $\mathrm{CH}_{2} \mathrm{Cl}_{2}, \mathrm{rt}, 95 \%$ (c); $\mathrm{TFA} / \mathrm{CH}_{2} \mathrm{Cl}_{2}$ (2/8-v/v), rt, quantitative (d); glutaric anhydride, pyridine, $\mathrm{CH}_{2} \mathrm{Cl}_{2}, \mathrm{rt}$, quantitative (e); (Gly) ${ }_{4}^{-}$ OtBu, HBTU, DIPEA, $\mathrm{CH}_{2} \mathrm{Cl}_{2}, \mathrm{rt}, 74 \%$; $\mathrm{TFA} / \mathrm{CH}_{2} \mathrm{Cl}_{2}(2 / 8$-v/v), rt, $92 \%$ (f); TFA/ $\mathrm{CH}_{2} \mathrm{Cl}_{2}(2 / 8-\mathrm{v} / \mathrm{v}), \mathrm{rt}, 92 \%$ (g). 
molar ratio excesses of fentanyl dose to estimated antibody binding sites by at least 2.5. The intravenous dose given to rats in the current study was approximately seven times higher than the intravenous dose that causes severe respiratory depression in humans (Dahan et al., 2005). Reduction of brain fentanyl has been reported by another group using one fentanyl vaccine after a $0.2 \mathrm{mg} / \mathrm{kg}$, s.c., fentanyl dose (Bremer et al., 2016), but this effect was not replicated in another study by the same group using a different fentanyl vaccine after a $0.1 \mathrm{mg} / \mathrm{kg}$, i.v., fentanyl dose (Hwang et al., 2018). Although there was no clear explanation for that discrepancy, differences in fentanyl vaccine potency between those two vaccines and differences in dosing route are most likely the cause. The drug-dosing route has been shown to affect addiction vaccine efficacy in at least one oxycodone vaccine, which showed greater reduction of brain oxycodone concentrations after subcutaneous dosing (44\% reduction) than after intravenous dosing ( $12 \%$ reduction), likely due to slower absorption after subcutaneous dosing compared with intravenous dosing (Raleigh et al., 2018). This route effect could have contributed to the large $(90 \%)$ decrease in brain fentanyl levels with vaccination in the current study when fentanyl was administered subcutaneously.

The doses of fentanyl used in the current study generated clinically relevant serum fentanyl concentrations in the range of $5-30 \mathrm{ng} / \mathrm{ml}$. In humans, therapeutic serum concentrations of fentanyl show a $C_{\max }$ ranging from 0.2 to $0.9 \mathrm{ng} / \mathrm{ml}$ after sublingual, intranasal, transmucosal fentanyl, or intravenous administration of fentanyl (Nave et al., 2013; Parikh et al., 2013), whereas unintentional overdose of transdermal patches show fentanyl blood concentrations ranging from 5 to $28 \mathrm{ng} / \mathrm{ml}$ (Jumbelic, 2010) and respiratory depression at plasma concentrations of $2.5-6.3 \mathrm{ng} / \mathrm{ml}$ in humans (Mildh et al., 2001).

One limitation is that control rats in Experiment 2 had an unexpectedly low \%MPE of $41 \%$. This low \%MPE may be due to the small therapeutic window of fentanyl, and the small deviations in the fentanyl dose given to rats may have greatly affected hotplate antinociception results in the current study. Nevertheless, F-KLH significantly reduced fentanyl-induced antinociception.

Fentanyl remains the most common fentanyl-like adulterant in counterfeit pills and most commonly abused fentanyllike opioids, and the use of fentanyl analogs changes rapidly with the emergence of new analogs and their availability (O'Donnell et al., 2017; Armenian et al., 2018). The current data suggest that F-sKLH could potentially be used as a prophylactic to reduce the side effects of fentanyl, alone or in conjunction with naloxone, and as a potential therapeutic agent for fentanyl abuse in humans.

\section{Acknowledgments}

We thank Danielle Burroughs for technical support.

\section{Authorship Contributions}

Participated in research design: Raleigh, Le Naour, Pentel, and Pravetoni.

Conducted experiments: Raleigh, Baruffaldi, Peterson, and Le Naour.

Contributed new reagents or analytical tools: Baruffaldi, Le Naour, Harmon, Vigliaturo, and Pravetoni.

Performed data analysis: Raleigh, Peterson, Le Naour, Pentel, and Pravetoni.
Wrote or contributed to the writing of the manuscript: Raleigh, Le Naour, Pentel, and Pravetoni.

\section{References}

Armenian P, Vo KT, Barr-Walker J, and Lynch KL (2018) Fentanyl, fentanyl analogs and novel synthetic opioids: a comprehensive review. Neuropharmacology 134 (Pt A):121-132.

Bazin-Redureau MI, Renard CB, and Scherrmann JM (1997) Pharmacokinetics of heterologous and homologous immunoglobulin G, F(ab')2 and Fab after intravenous administration in the rat. $J$ Pharm Pharmacol 49:277-281.

Boyer EW (2012) Management of opioid analgesic overdose. $N$ Engl J Med 367: 146-155.

Bremer PT and Janda KD (2012) Investigating the effects of a hydrolytically stable hapten and a Th1 adjuvant on heroin vaccine performance. $J$ Med Chem 55: 10776-10780.

Bremer PT, Kimishima A, Schlosburg JE, Zhou B, Collins KC, and Janda KD (2016) Combatting synthetic designer opioids: a conjugate vaccine ablates lethal doses of fentanyl class drugs. Angew Chem Int Ed Engl 55:3772-3775.

Bremer PT, Schlosburg JE, Banks ML, Steele FF, Zhou B, Poklis JL, and Janda KD (2017) Development of a clinically viable heroin vaccine. J Am Chem Soc 139: 8601-8611.

Bremer PT, Schlosburg JE, Lively JM, and Janda KD (2014) Injection route and TLR9 agonist addition significantly impact heroin vaccine efficacy. Mol Pharm 11 1075-1080.

Clarke SF, Dargan PI, and Jones AL (2005) Naloxone in opioid poisoning: walking the tightrope. Emerg Med $J$ 22:612-616.

Dahan A, Yassen A, Bijl H, Romberg R, Sarton E, Teppema L, Olofsen E, and Danhof $\mathrm{M}$ (2005) Comparison of the respiratory effects of intravenous buprenorphine and fentanyl in humans and rats. $B r J$ Anaesth 94:825-834.

DEA (2016a) Counterfeit prescription pills containing fentanyls: a global threat. DEA intelligence brief US Department of Justice, Washington, DC

DEA (2016b) National Drug Threat Assessment, US Department of Justice, Washington, DC.

Evans LE, Swainson CP, Roscoe P, and Prescott LF (1973) Treatment of drug overdosage with naloxone, a specific narcotic antagonist. Lancet 1:452-455.

Frank RG and Pollack HA (2017) Addressing the fentanyl threat to public health. N Engl J Med 376:605-607.

Henderson GL, Frincke J, Leung CY, Torten M, and Benjamini E (1975) Antibodies to fentanyl. J Pharmacol Exp Ther 192:489-496.

Hug CC Jr. and Murphy MR (1981) Tissue redistribution of fentanyl and termination of its effects in rats. Anesthesiology 55:369-375.

Huynh NH, Tyrefors N, Ekman L, and Johansson M (2005) Determination of fentanyl in human plasma and fentanyl and norfentanyl in human urine using LC-MS/MS. $J$ Pharm Biomed Anal 37:1095-1100.

Hwang CS, Smith LC, Natori Y, Ellis B, Zhou B, and Janda KD (2018) Efficacious vaccine against heroin contaminated with fentanyl. ACS Chem Neurosci 9 1269-1275.

Jones CM, Einstein EB, and Compton WM (2018) Changes in synthetic opioid involvement in drug overdose deaths in the United States, 2010-2016. JAMA 319: 1819-1821.

Jumbelic MI (2010) Deaths with transdermal fentanyl patches. Am J Forensic Med Pathol 31:18-21.

Langham S, Wright A, Kenworthy J, Grieve R, and Dunlop WCN (2018) Costeffectiveness of take-home naloxone for the prevention of overdose fatalities among heroin users in the United Kingdom. Value Health 21:407-415.

Le Bars D, Gozariu M, and Cadden SW (2001) Animal models of nociception. Pharmacol Rev 53:597-652.

Lister N, Warrington S, Boyce M, Eriksson C, Tamaoka M, and Kilborn J (2011) Pharmacokinetics, safety, and tolerability of ascending doses of sublingual fentanyl, with and without naltrexone, in Japanese subjects. J Clin Pharmacol 51: 1195-1204.

Matyas GR, Mayorov AV, Rice KC, Jacobson AE, Cheng K, Iyer MR, Li F, Beck Z, Janda KD, and Alving CR (2013) Liposomes containing monophosphoryl lipid A: a potent adjuvant system for inducing antibodies to heroin hapten analogs. Vaccine 31:2804-2810.

Mildh LH, Scheinin H, and Kirvelä OA (2001) The concentration-effect relationship of the respiratory depressant effects of alfentanil and fentanyl. Anesth Analg 93: 939-946.

Molina-Martínez LM, González-Espinosa C, and Cruz SL (2014) Dissociation of immunosuppressive and nociceptive effects of fentanyl, but not morphine, after repeated administration in mice: fentanyl-induced sensitization to LPS. Brain Behav Immun 42:60-64

Nave R, Schmitt H, and Popper L (2013) Faster absorption and higher systemic bioavailability of intranasal fentanyl spray compared to oral transmucosal fentanyl citrate in healthy subjects. Drug Deliv 20:216-223.

O'Donnell JK, Halpin J, Mattson CL, Goldberger BA, and Gladden RM (2017) Deaths involving fentanyl, fentanyl analogs, and U-47700 - 10 states, July-December 2016 MMWR Morb Mortal Wkly Rep 66:1197-1202.

Parikh N, Goskonda V, Chavan A, and Dillaha L (2013) Single-dose pharmacokinetics of fentanyl sublingual spray and oral transmucosal fentanyl citrate in healthy volunteers: a randomized crossover study. Clin Ther $\mathbf{3 5}$ : 236-243.

Peckham EM and Traynor JR (2006) Comparison of the antinociceptive response to morphine and morphine-like compounds in male and female Sprague-Dawley rats. $J$ Pharmacol Exp Ther 316:1195-1201.

Pravetoni M, Le Naour M, Harmon TM, Tucker AM, Portoghese PS, and Pentel PR (2012a) An oxycodone conjugate vaccine elicits drug-specific antibodies that reduce oxycodone distribution to brain and hot-plate analgesia. J Pharmacol Exp Ther 341:225-232. 
Pravetoni M, Le Naour M, Tucker AM, Harmon TM, Hawley TM, Portoghese PS, and Pentel PR (2013) Reduced antinociception of opioids in rats and mice by vaccination with immunogens containing oxycodone and hydrocodone haptens. $J \mathrm{Med}$ Chem 56:915-923.

Pravetoni M, Raleigh MD, Le Naour M, Tucker AM, Harmon TM, Jones JM, Birnbaum AK, Portoghese PS, and Pentel PR (2012b) Co-administration of morphine and oxycodone vaccines reduces the distribution of 6-monoacetylmorphine and oxycodone to brain in rats. Vaccine 30:4617-4624.

Raleigh MD, Laudenbach M, Baruffaldi F, Peterson SJ, Roslawski MJ, Birnbaum AK, Carroll FI, Runyon SP, Winston S, Pentel PR, et al. (2018) Opioid dose- and route-dependent efficacy of oxycodone and heroin vaccines in rats. $J$ Pharmacol Exp Ther 365:346-353.

Raleigh MD, Pentel PR, and LeSage MG (2014) Pharmacokinetic correlates of the effects of a heroin vaccine on heroin self-administration in rats. PLoS One $\mathbf{9}$ e115696.

Raleigh MD, Peterson SJ, Laudenbach M, Baruffaldi F, Carroll FI, Comer SD, Navarro HA, Langston TL, Runyon SP, Winston S, et al. (2017) Safety and efficacy of an oxycodone vaccine: addressing some of the unique considerations posed by opioid abuse. PLoS One 12:e184876.

Raleigh MD, Pravetoni M, Harris AC, Birnbaum AK, and Pentel PR (2013) Selective effects of a morphine conjugate vaccine on heroin and metabolite distribution and heroin-induced behaviors in rats. J Pharmacol Exp Ther 344:397-406.

Riches JR, Read RW, Black RM, Cooper NJ, and Timperley CM (2012) Analysis of clothing and urine from Moscow theatre siege casualties reveals carfentanil and remifentanil use. J Anal Toxicol 36:647-656.

Rudd RA, Seth P, David F, and Scholl L (2016) Increases in drug and opioid-involved overdose deaths - United States, 2010-2015. MMWR Morb Mortal Wkly Rep 65 $1445-1452$
Rzasa Lynn R and Galinkin JL (2018) Naloxone dosage for opioid reversal: current evidence and clinical implications. Ther Adv Drug Saf 9:63-88.

Schlosburg JE, Vendruscolo LF, Bremer PT, Lockner JW, Wade CL, Nunes AA Stowe GN, Edwards S, Janda KD, and Koob GF (2013) Dynamic vaccine blocks relapse to compulsive intake of heroin. Proc Natl Acad Sci USA 110:9036-9041.

Schneider E and Brune K (1986) Opioid activity and distribution of fentanyl metabolites. Naunyn Schmiedebergs Arch Pharmacol 334:267-274.

Seth P, Scholl L, Rudd RA, and Bacon S (2018) Overdose deaths involving opioids, cocaine, and psychostimulants - United States, 2015-2016. MMWR Morb Mortal Wkly Rep 67:349-358. Stowe GN, Vendruscolo LF, Edwards S, Schlosburg JE, Misra KK, Schulteis G, Mayorov AV, Zakhari JS, Koob GF, and Janda KD (2011) A vaccine strategy that induces protective immunity against heroin. J Med Chem 54:5195-5204.

Tomassoni AJ, Hawk KF, Jubanyik K, Nogee DP, Durant T, Lynch KL, Patel R, Dinh D, Ulrich A, and D'Onofrio G (2017) Multiple fentanyl overdoses - New Haven, Connecticut, June 23, 2016. MMWR Morb Mortal Wkly Rep 66:107-111.

Torten M, Miller CH, Eisele JH, Henderson GL, and Benjamini E (1975) Prevention of the effects of fentanyl by immunological means. Nature 253:565-566.

Wheeler E, Jones TS, Gilbert MK, and Davidson PJ; Centers for Disease Control and Prevention (CDC) (2015) Opioid overdose prevention programs providing naloxone to laypersons - United States, 2014. MMWR Morb Mortal Wkly Rep 64:631-635.

Wong J (2012) Naloxone and nalmefene, in Poisoning and Drug Overdose (Olson KR ed) pp 514-517, McGraw Hill, New York.

Address correspondence to: Michael D. Raleigh, Hennepin Healthcare Research Institute, 701 Park Avenue, Suite \#S3.340, Minneapolis, MN 55415. E-mail: rale0011@umn.edu 